UDC 656.131 .2

http://doi.org/10.21272/mmi.2019.2-11

JEL Classification: L91, M21, 018, P25

Jiri Mezulanik,

D.Sc., University of Business and Law, Czech Republic

Lubomir Kmeco,

Ph.D., University College of Business in Prague, Czech Republic

Mehmet Civelek,

Ph.D., Tomas Bata University in Zlin, Czech Republic

Jirka Kloudova,

Ph.D., University of Entrepreneurship and Law, Czech Republic

\title{
TRANSPORT SERVICES IN THE SHARED ECONOMY SEGMENT COMPARED TO TRADITIONAL TAXI SERVICES: THE CASE STUDY OF THE CZECH REPUBLIC
}

\begin{abstract}
This research deals with the arguments within the scientific discussion on the issue of shared economy in the field of passenger transport in the Czech Republic. The main purpose of the research is to compare some ridesharing platforms, namely, Uber, Liftago and Taxify and traditional taxi services regarding their starting rates and a characteristic of the cars that they use. Investigation of the topic shows that starting rates and quality of services of these platforms differ regarding the locations and ride-hailing services. Therefore, analysing various sharing economy platforms in the Czech Republic regarding transportation and finding differences among them might create value addition for sharing economy literature. In this regard, this paper applies a research technique that consists of interviews and direct observation in the provision of transport services. In the research, a primary survey was carried out; In terms of secrecy, scenarios of interviews and cover-stories were prepared to motivate respondents to more open communication. Respondents were providers of transport services in the form of classic taxis, Uber, Liftago and Taxify, the most important providers of passenger taxis in the monitored cities. The research was carried out in 2017/2018 in different cities of the Czech Republic, namely, Prague and Ostrava. The obtained data were processed in the SPSS IBM Statistics program using the methods of descriptive statistics. The results of the research show that in the analysed parameters, the ride-hailing platforms do not provide cheaper services in the monitored markets and that their prices are comparable to those of traditional providers. For this reason, travellers, users and providers of ride-hailing services can benefit from this study by considering the differences that this research proves.
\end{abstract} Uber.

Keywords: platform economy, ride-hailing, ridesharing, ride-sourcing, sharing economy, transportation industry,

Introduction. Due to its solutions for environmental, social, economic and communicational issues, sharing economy has become a hot topic not only in business lines but also in the academic field. Developments in innovative technologies have played a major role in increased importance of sharing economy and have enabled peer to peer platforms to enhance rapidly by providing easier conditions for individuals and companies to access to service providers and markets. Sharing economy concept has also called with different names by existing studies such as accessed based consumption, collaborative economy, peer to peer economy, commercial sharing systems, collaborative consumption, consumer participation and co-creation.

This phenomenon mainly purposes to share and to consume goods or services that are idle or slightly used. Tangible and intangible assets can be shared through online platforms. Therefore, it changes consumption patterns and buying behaviour of people. Moreover, it enables individuals to contact with other people and strengthens existing relations with them. According to PWC (2015), the size of sharing economy in global market reached around US\$15 billion in 2015 and it is estimated that the size will attain US\$335 billion in 2025 (PwC, 2015). Collaborative consumption includes three-sided interactions among individuals, service providers and sharing economy platforms, while trust is the most

Cite as: Mezulanik, J., Kmeco, L., Civelek, M. \& Kloudova, J. (2019). Transport Services in the Shared Economy Segment Compared to Traditional Taxi Services: The Case Study of the Czech Republic. Marketing and Management of Innovations, 2, 118-130. http://doi.org/10.21272/mmi.2019.2-11 

Traditional Taxi Services: The Case Study of the Czech Republic

common obstacle that those parties face in sharing economy (Zhang et al., 2019). A platform gathers service providers and customers into an online system by applying information technologies to form interaction between both sides. In this regard, network services play a vital role to meet the expectations and demands of customers. For this reason, online sharing economy platforms make vast amount of investments to new technologies to improve quality of their services or to generate new management systems (Zuo et al., 2019). These new technologies have enabled convenient communication, transportation, accommodation and borrowing opportunities. (Alizadeh et al., 2018). In this regard, emergence of new trends in on-demand transportation regarding sharing economy activities have also influenced individuals' choices in travelling, then have become more widened among travellers.

Regarding to transportation, car hailing is one of the most common business models of sharing economy. Transportation activity in sharing economy is also named differently such as ride hailing, car hailing, on demand rides and ride sourcing (Cheng et al., 2018; Zuo et al., 2019). Companies in this ridesourcing platforms called themselves as Transportation Network Companies and Mobility Service providers. Uber, Lyft, Didi, Ola, UberMOTO, BlaBlaCar, Didi Hitch, Liftago are the examples of ridesourcing companies that operate in some countries such as USA, India, Thailand, France, China and Czech Republic. Other concepts also exist in transportation industry, namely ride sharing (ride splitting, car sharing). Examples for this type sharing economy platforms are Zimride, RelayRides, UberPool and Lyft Line. There are also some groups in social media and they search for ridesharing options. For instance, Nebengers enables their members to contact via Twitter and then provides application that serves as peer to peer platform (Asirin and Azhari, 2018). UberBlack, UberSUV, UberX, Zipcar, Sidecar are other types of sharing economy platforms that provides different services such as renting cars or giving membership to drive cars in a carfleet. On the other hand, development in technologies also have made some taxi companies to use online applications to interact with their customers. The examples of taxi applications are, Grap Taxi in Singapore, 99 Taxi and Easy Taxi in Brazil.

Regarding transportation industry, primary benefits of sharing economy platforms in this sector to ensure environmental sustainability by reducing emissions that cause global warming and climatic changes. Other benefits that sharing economy provides for transportation industry are cost reductions in operational, transactional, personal and maintenance costs for businesses. This makes transportation platforms to deploy their resources (Melo et al., 2019; Velychko, 2017). In comparison with public transport, these sharing economy platforms in transportation industry also save passengers' time.

Ride sourcing is most common type of sharing economy platform regarding transportation. According to Young and Farber (2019) more than 20\% adults of USA experience ride sourcing services. In comparison with public transport, ridesourcing brings drivers and passengers together in private vehicles (Jin et al., 2018). The business model of ride sourcing lets travelers to request a journey in scheduled time through an application or an online network by a smartphone (Cheng et al., 2018; Zuo et al., 2019). Travelers, riders, financial institutions or firms are contacted by ride sourcing platforms that include activities such as making payments and booking transportation through internet. Mechanisms of those platforms consist of a matching algorithm that enables to see available riders for passengers (Zuo et al., 2019). These applications also show prices for a requested trip (Egan et al., 2018) and those prices are usually cheaper comparing to traditional taxi services. Although they have not existed for many years, Uber and Lyft, have had a high share in transportation industry and they still increase their market share. Although, these companies have no cars and workers, they have attained success (Young and Farber, 2019) and they have services for disabled people too (Jin et al., 2018).

Another most common type of transportation platform is ride splitting (ridesharing, carsharing). Ride splitting gives chance to individuals to travel with other people that have similar route with them. By sharing the trip, passengers also split the fee (Jin et al., 2018). These services are widely used especially in big cities of USA and Europe because driving their own private cars is costlier for people 

Traditional Taxi Services: The Case Study of the Czech Republic

comparing to using these services (Stuchly and Suta, 2019). On the other hand, in comparison with ridesourcing services, the fees of ride splitting platforms such as Lyft Line and UberPool are also cheaper. This is because drivers of ride sourcing services ride their vehicles depending on passengers' requests while routes in ride splitting services are mostly based on the destination of the drivers (Schwieterman and Smith, 2018). Apart from their advantages, sharing economy platforms have caused some market distortions in transportation industry especially in market entrance of Uber. Moreover, these platforms have also faced with some criticisms regarding safety, traffic, labour, legal issues. Some authors also criticize about negative influences of these services by exampling deteriorations in social behaviours (Alizadeh et al., 2018).

All positive and negative influences of Transportation Network Companies on economy and social life have drown researchers' attention. In this regard, some of them make comparisons between traditional taxis and ride sourcing services (Davidson an dlnfranca, 2016; Young and Farber, 2019), while other researchers compare incomes of drivers in taxi and transportation network companies (Jin et al., 2018; Kljucnikov et al., 2019). Some studies also investigate cost and advantages of using these services for passengers (Schwieterman and Pelon, 2017). Moreover, characteristics of travellers that use applications of these platforms (Rayle et al., 2016) and the differences between both public transportation and online transportation platforms (de Souza Silva et al., 2018) have been also examined by some scholars. On the other hand, working and business conditions of service providers (Cheng et al., 2018) consumer behaviour and passengers' consumption patterns (Zhang et al., 2019; Sharp, 2018). Furthermore, government regulations and tax issues regarding transportation network companies (Sun et al., 2018), the hours that these services are most frequently used (Murphy and Felgon, 2016), environmental (Melo et al., 2019) and medical issues (Hall et al., 2017; Greenwood and Wattal, 2017) have discussed by existing studies in the literature. Technological developments and processes of transportation applications (Zuo et al., 2019) and the differences between ride sourcing and ride splitting network companies have also analysed by some researchers (Gargiulo et al., 2015; Schwieterman and Smith, 2018).

Literature Review. Although, the opinion of sharing economy firstly came into existence in the late 1970s (de Souza Silva et al., 2018), the sharing economy came into prominence especially in last decade. It provides a new phenomenon that directs entrepreneurs or businesses to produce, to share consumption of goods and services by using online platforms in current technologies (Tussyadiah and Pesonen, 2015). By doing so, sharing economy activities reach potential customers (de Souza Silva et al., 2018) who can benefit from these sources with easier access conditions and search for transportation, accommodation, entertainment, finance, and other activities of sharing economy. Therefore, businesses have created new applications or websites to draw consumers' attentions to sell or share their goods and services (de Souza Silva et al., 2018). Uber and Airbnb can be good examples for this peer to peer transportation and accommodation services (Tussyadiah and Pesonen, 2015).

The sharing economy firstly defined as collaborative consumption that requires one or more individuals to use up goods and services with other people by peer to peer transactions (Zhang et al., 2019; de Souza Silva et al., 2018). Sharing economy highlights the sharing as forming a new opinion to set up a business by cooperating with more stakeholders (Zhang et al., 2019). It involves various procedures such as online communication and electronic commerce. Moreover, service providers do not face with restrictions to enter the markets, can easily enrol in those sharing economy platforms and are not required to gain acceptation from policy makers. Most of the sharing economy platforms also do not require any fixed working hours and standard services. Therefore, service providers feel free to arrange flexible working hours and their services can be varied (Cheng et al., 2018; Kljucnikov et al., 2018).

On the other hand, purchasers in the sharing economy, have rapidly changed their transactions and buying behaviour through the existing platforms by using various ways of investigating, experiencing and 

Traditional Taxi Services: The Case Study of the Czech Republic

making payments. Therefore, it effects living and business conditions of people (Zhang et al., 2019). The idea of sharing economy is also nature friendly because instead of using new goods, it motives people to consume existing products. Thus, demand of novel goods decreases (Jin et al., 2018). Some scholars explain another reason for the increasing importance of sharing economy by emphasizing global warming. Recently, people has become more concerned about this issue and to hinder it they look for collective consumption methods that can also provide advantages for consumers such as reducing living expenses. The sharing economy disrupts traditional consumptions patterns by creating conflicts among sharing economy platforms and traditional businesses that provide services such as taxi, and hotels. Although, these platforms include non-trained individuals who present services, because of their convenient price and service policies, they create difficulties for traditional businesses (Zhang et al., 2019).

When it comes to transportation industry, the large part of public transport is supplied by buses and railways. Even some regulations and financial supports carry out to improve public transportation, it still might not have very flexible services and might have problems regarding sufficiency of services. When individuals face with urgent situations, public transports are usually undersupplied. Moreover, number of railway stations lack and existing stations usually become distanced to living quarters. In this regard, sharing in transportation has gained prominence particularly in metropolises and has increased rapidly in these places regarding to traffic issues.

In 1948, the primary concept of shared transportation emerged in Switzerland and it was called as carsharing. However, this concept was not successful to draw individuals' attention and the usage of this service remained in low proportion (Sun et al., 2018). However, transportation choices of individuals have changed by emerging new platforms such as Uber and these platforms make policy makers to take some initiatives to solve existing problems in transport industry (Sharp, 2018). Especially, between the years of 2006 and 2018, the usage of shared transportation services among people increased to a large extent approximately 15 times more (from 0.35 to 5.95 million) (Sun et al., 2018). Thus, sharing economy platforms in transportation has deteriorated the conditions of taxis (Davidson and Infranca, 2016). Due to having different characteristics from traditional taxi services, such as flexibility in labour force, applying emerging technologies, having efficient matching and payment systems (Young and Farber, 2019), trustworthiness of price and rating mechanisms (Rayle et al., 2016) make ride hailing services more favourable and preferable than taxi industry. These platforms also provide benefits for their users by providing lower costs, confidence, suitability for their activities and save passengers' time. (Sharp, 2018; Jin et al., 2018; Young and Farber, 2019; Rayle et al., 2016). Depending on demand, prices of using these services can change (Young and Farber, 2019; Schwieterman and Pelon, 2017; Schwieterman and Smith, 2018) and it becomes more difficult to make a forecast for prices (Rayle et al., 2016). Some different price mechanisms exist in ride sourcing services namely posted price (PP) and double auction. PP mechanism gives chances to travellers and riders to approve or refuse fees that are charged by ride sourcing companies. Double auction mechanism is based on on-demand trips and enable travellers to indicate the fee that they can pay, while riders state the price that passengers have to pay. Therefore, both parties of transportation play active roles in this pricing mechanism that is efficient method especially where a large number of passengers and drivers exists (Egan et al., 2018). Lack of available drivers or scantiness of number of vehicles can also cause increases in prices, therefore, there is not any fixed price in transaction network companies such as Lyft and Uber. These price increases occur especially in rush hours, and when special cases exist such as concerts. In comparison to traditional taxis, the increase in the number of TNC vehicles had been in larger extent. Moreover, transportation demand of passengers has shifted from public transport to TNCs (Schwieterman and Smith, 2018). 

Traditional Taxi Services: The Case Study of the Czech Republic

In comparison with traditional taxis, ride sourcing services make passengers to wait shorter time (Rayle et al., 2016). By using these services individuals do not look for parking space, therefore, they also do not travel for more kilometres. Those services also had decreased the transfers of passengers between different transportation options in their travels (Young and Farber, 2019). Other reasons why passenger use these services are, nonexistence of available taxis and public transport, facility of payment, convenience in calling a car (Rayle et al., 2016). The increases in the usage of ridesourcing services reduce the number of passengers that use taxis (Young and Farber, 2019; Hall et al., 2017). Ridesourcing companies serve in wide area where the number of traditional taxi services lacks such as suburban. These facts can change consumer behaviours and consumption patterns. For instance, shared transportation might decrease desire of individuals to buy a new car (Jin et al., 2018). By analysing 4500 respondents in USA, Shared-Use Mobility Center (SUMC, 2016) find that passengers who used shared transportation options were prone to use public transport than other people because most of them did not have their private cars. Another finding of this research highlighted that the usage of ridesourcing options was higher for those travellers comparing to other platforms of sharing economy, namely carsharing and bikesharing (Schwieterman and Smith, 2018).

Riders travel with passengers depending on passengers' destinations as it is performed by traditional taxi services. By doing so, these services lower the number of cars that can be on the road, and so decrease traffic congestion (Jin et al., 2018). Moreover, those services also decrease the number of people who ride their private cars when they are drunk (Young and Farber, 2019; Rayle et al., 2016). Because of decreasing the number of drunk drivers, ride sourcing services also reduce traffic accidents, and so fatal accidents too. Hence, ride hailing platforms provide benefits for community health care (Hall et al., 2017; Greenwood and Wattal, 2017). Ride sourcing is also substantial for urban environmental sustainability because it decreases consumption of energy, petrol and greenhouse gas emissions. Thus, it also increases the efficiency of energy usage (Jin et al., 2018).

Ridesourcing also varies from traditional taxis by using online platforms and applications that people can log in by their smartphones to arrange their travels (Rayle et al., 2016). Although some cabs have taxi hailing systems, ride sourcing applications make passengers to pay the price of their trip by credit cards through these platforms (Rayle et al., 2016; Jin et al., 2018). Therefore, people who do not have credit cards or bank accounts are not able to yield from benefits of Transportation Network Companies (TNC). Although users of these platforms are concerned about sharing of their private data, TNC companies care about safety and privacy of data that passengers and riders share it through these applications (Jin et al., 2018). Passengers also can book a car, interact with drivers and drivers and passengers can grade each other when the trip is completed (Rayle et al., 2016). Cheng et al. (2018) and Zuo et al. (2019) define processes of car hailing services with four different stages, namely, request of a passenger for a trip, acceptation of the request by a driver, travelling, electronic payment and rating. Zuoand Chen (2017) add another process, namely, the choice of a platform at the beginning of this procedure. Online and offline services exist in these stages of transportation platforms. Offline services become completed when passengers are picked up by riders' private vehicles and driven them to final destination, while online transactions include requesting a trip, acceptation of the request and payment of the travel fee (Zuo et al., 2019). When a service provider approves a requested trip, the traveller can see all details about the riders, such as time of arrival. The platforms provide navigation for riders to find the location of the passenger easily, thus, it enables to reduce time of searching and travel costs. Drivers of ride sourcing services also pay fees to these transportation network companies (Rayle et al., 2016). Drivers of these platforms do not need to have licences, use their private cars and their working hours are flexible (Schwieterman and Smith, 2018; Rayle et al., 2016; Young and Farber, 2019).

Regarding to peak use period of these shared transportation services, existing studies have similar results. Since services of public transportation are less often during nights and weekends comparing to 

Traditional Taxi Services: The Case Study of the Czech Republic

daytime and ordinary working hours, the users of ride sourcing mostly apply this transportation option especially during late night hours and weekends (Young and Farber, 2019; Jin et al., 2018). Young and Farber (2019) state that passengers benefit from these services especially in the evening in New York, while Murphy and Felgon (2016) reveal that individuals rarely use these services in rush hours of morning and evening. Ride sourcing is also very competitive with public transportation particularly in places where the density of traffic is high. For instance, the surveys of The American Public Transportation Association (APTA, 2016), Rayle et al. (2016) and Henao (2017) confirmed that around $15-35 \%$ of passengers used public transport when travelling with ride sourcing services were not possible. This percentage was higher for people who did not have their private cars (Rayle et al., 2016). Corresponding to characteristics of users, many researches prove that the users of ridesourcing services mainly consists of more educated, younger and wealthier people (Rayle et al., 2016; Jin et al., 2018; Young and Farber, 2019). People who are younger (Young and Farber, 2019) better educated and have higher wages are more likely to have smart phones and use them more than other people. Therefore, they are more prone to use ride sourcing services in comparison to other people (Jin et al, 2018). In their study, Young and Farber (2019) found that fewer than $2 \%$ of individuals who used ride sourcing services, were more than 59 years old. Apart from all its benefits, there have been many criticisms to ridesoursing services regarding, its safety, causing traffic jam, disrupting labour market and breaking the rules (Hall et al., 2017). Especially taxi drivers had become opposed when ridesourcing services had emerged (Zuo et al., 2019; Rayle et al., 2016; Hall et al., 2017) because they had perceived that these services were illegal and create imperfect competition in the taxi industry by being tax free (Rayle et al., 2016). Moreover, drivers of ridesourcing services are not liable to labour and supply regulations of taxi drivers. For instance, it is not required for them to follow safety standards and to drive their cars for a certain amount of money that is specified by government or other institutions (Rayle et al., 2016; Young and Farber, 2019).

Because of the political power of taxi sector, the competition between taxi, ride sourcing and public transport companies has been fierce and aggressive. To cope with these issues, some governments and authorities use their legislative power and make some regulations to hinder disruptive transportation services (de Souza Silva et al., 2018). Some cities have combined public transport and ride sourcing services to overcome existing problem in the market. For instance, because of high expenses and high costs of two bus lines, Uber and Lyft services used for these lines by the decision of government in Tampa USA (de Souza Silva et al., 2018). Young and Farber (2019) suggest that to close the gap among taxi and ride sourcing services, policy makers can require licenses, safety applications, and criminal history for riders of ride sourcing companies as they do for drivers of taxi sector. Many platforms exist to perform ride sourcing services, but Uber is the leading platform between these companies all over the world (Egan et al., 2015). In 2009, Uber established in the USA, and quickly boomed its services by collaborating with riders that had their private car (Schwieterman and Smith, 2018). Although, access of Uber services in cities sparked a debate especially in taxi industry, Uber presented safe and well-priced travelling options by considering ignored routes (Hall et al., 2017). The marketing value of Uber is around $\$ 70$ billion and it operates in more than 450 cities. This company also makes different activities such as collaborating with Dubai's transport authority (Sharp, 2018). Instead of being a part of existing business models, Uber took advantages from legal gaps and looseness of regulations, when it established. However, when policy makers became aware of this situation, they imposed sanctions. Therefore, Uber faced many legal actions all over the world in relation with labour laws, commercial activity, insurance and consumer rights. Uber was also met by protests in some countries such Spain, Germany, Slovakia, Brazil and Indonesia. Moreover, France, Italy and Spain forbad the services between passengers and riders that did not have license (Stalmasekova et al., 2017). Due to decreasing ridership for public transport, Uber services influence government budget. The reciprocal 

Traditional Taxi Services: The Case Study of the Czech Republic

influences among public transportation and Uber, also impact traffic jam, and pollution because the number of total travels rises. Traffic congestion and pollution increase in a larger extent if Uber has larger substitution effect against public transport (Hall et al., 2017). Since, safety requirements do not exist for Uber services, some of vehicles that operate under this company might not have insurance or can be underinsured (Jin et al., 2018). On the other hand, Uber services have some advantages for passengers, drivers and environment as other ridesourcing services. Although, vehicles of public transportation usually serve at certain times for certain routes, routes and time of travelling depend on passengers' demand in Uber services. Therefore, Uber services save time and present more suitable trips comparing to public transportation (Hall et al., 2017). Because of rating and tracking systems of Uber application, both travellers and riders perceive these services as safe. Moreover, travellers can be informed about rider and they are able to view whether the requested vehicle is coming or not (Jin et al., 2018). Uber application that can be access by smartphones, provides up-to-date information and predicted journey time. The usage of public transportation together with Uber services can satisfy all transportation demand of travellers. Therefore, individuals might not need to buy a private vehicle (Hall et al., 2017). Although the services of Uber are costlier than public transportation for passengers (Young and Farber, 2019; Hall et al., 2017), these services are cheaper than traditional taxi services (Young and Farber, 2019; Hall et al., 2017). Other studies also find similar results that UberX services are less costly for individuals comparing to traditional taxis (Greenwood and Wattal, 2017; Hall et al., 2017; Jin et al., 2018). Although, the cost of Uber services can differ regarding to demand of passengers, prices of taxis are usually fixed (Jin et al., 2018). Jin et al. (2018) also found that traditional taxis were more slowly than UberX and the prices of travelling with traditional taxis were more than UberX trips. Access of Uber services in Taiwan market, decreased ridership of traditional taxi services around 12 to $18 \%$ in first three years (Chang, 2017). Uber also decreases the cost of transactions for passengers and enable them to call a vehicle from indoor without waiting on the way (Rogers, 2015). On the other, Jin et al. (2018) examined traffic congestion in New York in 2014 and expressed that Uber did not deteriorate traffic jam in rush hours because the percentage of Uber cars was very low in the total number of vehicles that were on the way. Two years after its emergence, Uber had decreased ridership of several public transportation companies in the US. Uber also plays complementary roles to close the gaps among the lines of public transportation by providing convenient trips and its availability when needed especially in neglected areas. Moreover, stations of public transportation can be far from destinations of passengers. For this reason, the time that passengers spend to go to stations can be the large part of their travelling time. In this case, using Uber services can make travellers to save their time and provide an option to have a trip without transferring to other transportation options (Hall et al., 2017). Similarly, when new a new railway stations builds, number of Uber trips increases because it is a convenient service for travellers to have a trip between the new station and their destination (Jin et al., 2018). Therefore, around $25-40 \%$ of Uber services were performed close to public transportation stops in different cities (Hall et al., 2017). Regarding service flexibility, drivers of Uber services can remove themselves from this platform when they are not available and other available drivers can be listed by travellers (Zervas et al., 2017). By analysing, Uber services in Prague, Kljunickov et al. (2019) compare incomes of taxi drivers and Uber riders. When drivers of Uber services perform these actions as full-time employees their income will be more than licensed drivers of traditional taxi services. Providing Uber services in rush hours makes drivers to get more income than taxi drivers. When riders of transportation services such as taxi and Uber drivers, use their private cars in their trips, they gain more advantages than riders who travel with rented cars. Jin et al. (2018) also find similar results with Kljucnikov et al. (2019) and reveal that in comparison with riders of Uber, incomes of riders of traditional taxis for per hour is lower. One of the Czech ride sourcing services that has been operating in Prague is Liftago (Kljunickov et al., 2019). Although Liftago is a Czech firm it also serves in Slovakia too (Stalmasekova et al., 2017). Liftago uses 

Traditional Taxi Services: The Case Study of the Czech Republic

different pricing mechanism than Uber services, namely auction-based, while Uber applies data-driven method. The method of Liftago includes four stages that are offer of a traveller for a trip, Liftago's search for appropriate drivers for the requested trip, drivers' bids to the traveller, the choice for a bid by the traveller and its payment (Egan et al., 2015). According to Kljucnikov et al. (2019) the number of Uber drivers in Prague is around 2000. Their results show that the drivers of Uber Pop and Uber Select services get lower incomes than taxi drivers. Only Uber Black's drivers have similar incomes with the riders of traditional taxi services. Hidden costs of Uber Pop and Uber Select services make drivers of to have less income than the average salary of a rider in the Czech Republic. Kljucnikov et al. (2019) also confirm the non-existence of tax evasions among drivers of ridesourcing services in Prague. The average earnings for per mount before taxes involving explicit and implicit costs for drivers of Uber Pop services is around 61.5 EURO, while the average income of Uber Select riders is around 163.58 EUR.

In order to increase their market share, several Transportation Network Companies (TNC) have provided new services such as ridesplitting (Jin et al., 2018). In 2014, Uber and Lyft started to provide ride splitting services by their new platforms namely UberPool and Lyft Line. Passengers who use those services share a trip and its cost with other travellers (de Souza Silva et al., 2018; Schwieterman and Smith, 2018). The purpose of these platforms to increase carpooling activities and occupancy rate of the shared vehicles (Gargiulo et al., 2015; de Souza Silva et al., 2018). The idea of carpooling plays a crucial role for income of ridesourcing providers, sustainability and efficiency of their services. However, this concept faces with legal problems regarding legislation of transportation in some states. For instance, the California Public Utilities Commission (CPUC) identified carpooling activities as illegal in 2014 (de Souza Silva et al., 2018). Ridesourcing and ridesharing platforms differ because drivers of ridesourcing platforms drive their private cars upon passengers' requested destinations and by doing so they aim to increase their income (Rayle et al., 2016). On the other hand, in the ride sharing (ride splitting) platforms, drivers specify their own trip through the applications. Lyft Line and UberPool can be examples for ridesharing platforms. In these transportation network companies, travellers have chances to change the routes of drivers depending on their demands (Schwieterman and Smith, 2018). Moreover, UberPool made a campaign for people who lived in New York by giving them unlimited travels. The monthly cost of this unlimited trips was less expensive than the price of monthly unlimited public transport in New York (Jin et al., 2018). According to research of Schwieterman and Smith (2018), when it comes to travels from close vicinities, individuals who use UberPool platform, save $0.38 \$$ for per minute. The researchers also confirm that comparing to Uber $X$ that provides pick up service from the given address of passengers, Lyft Line and UberPool are less costly for customers. Furthermore, UberBlack and UberSUV are different services of Uber. UberBlack and UberSUV services are based on renting cars and licenses for riders that make them to differ from Uber's activities. Considering to all travels of Uber platform, $53 \%$ of them performed by UberX, while this percentage for UberBlack and UberSUV was $8 \%$. On the other hand, Lyft and Sidecar presented $30 \%$ and $7 \%$ of travels respectively (Rayle et al., 2016). Zipcar car sharing concept is another transportation option for an example of collective consumption activities. Zipcar has its own vehicle fleet in America and Europe and it provides options for its members to use the cars by paying annual fee. After the payment, members receive cards that enable them to drive their cars that they booked from an online system. Members can take the reserved vehicle from a location and then ride it back to this location when they run out of time that have already specified in their reservation. Members do not pay for insurance, petrol and parking expenses. A credit card exists in the car and members can fuel the car up by this card. The usage of car sharing has increased and then Avis took over Zipcar. This phenomenon has awakened big companies' interest and Daimler Benz, Car2Go, BMW and Peugeot have generated their car sharing services (Belk, 2014). Another ride sourcing service that has been operating worldwide is Didi. Didi services performed around 400 cities in 2017 and the number of trips that were driven by Didi's vehicle was higher than Uber. Didi 

Traditional Taxi Services: The Case Study of the Czech Republic

also works with other names in different countries such as Hitch in China (Zuo et al., 2019). Other applications exist all over the world and they can also be used as taxi hailing services. For instance, 99 Taxi and Easy Taxi are the applications that individuals use in Brazil. Both of those applications make taxi hailing systems more convenient. Because of Uber's access to Brazilian market, these platforms began to make discounts in their prices, therefore, passengers gained advantages from this competition (de Souza Silva et al., 2018).

Methodology and research methods. The paper is based on extensive research Development of a cost-benefit analysis method for transport services in the shared economy and on the edge (i.e. within the so-called shared and platform economy) through the creation of a data base and its pilot verification, which was carried out at the University of Entrepreneurship and Law within the BETA II Program of the Technology Agency of the Czech Republic (project number TI00UVCR001MT09). The project submitter was the Office of the Government of the Czech Republic. The subject of the research was the current position of transport service providers in the shared economy sector in relation to traditional taxi services in the Czech Republic. At present, it is a relatively significant socio-economic problem, which is reflected in the insufficient legislative anchorage of transport services in the shared economy sector, in the economic conditions of operation of this service, technical requirements for the provision of this service, etc. The research was carried out by a primary, research technique, a combination of direct observation and personal interviewing of drivers during the provision of transport services. In terms of secrecy, scenarios of interviews and cover-stories were prepared to motivate respondents to more open communication. A total of 136 interviews were conducted. Respondents were providers of transport services in the form of a classic taxi, as well as platform carriers Uber, Liftago and Taxify, the most important providers of passenger taxis in the monitored cities. The research was carried out in 2017/2018 in Prague and Ostrava. Interviewers (1 interviewer in Ostrava, 7 interviewers in Prague) were trained for the purposes of their own research. For the recording of the collected data, the Driving Record Form was processed. The obtained data were processed in the SPSS IBM Statistics program using the methods of descriptive statistics. From the available resources mentioned above, it is clear that the transport services provided by carriers from the shared economy sector are considered to be at a lower price, but of lower quality compared to traditional providers. The aim of the research was to verify this hypothesis by analysing selected criteria in providing transport services with a focus on shared economy. Starting rates, rates per kilometre between passenger service providers have been analysed, which are always the basic criteria when choosing a service provider. The age of the vehicle was chosen as a qualitative parameter, where it is assumed that the incentive to provide shared transport services is extra income (which has been shown in the wider research) and therefore the providers will have older cars because the conditions for the provision of shared transport services are not regulated. unlike traditional taxis, where there are clearly given limits to the age of the car. These criteria were formulated into three research questions: 1 . Are the starting rates provided by carriers from the shared economy sector lower than for traditional carriers? 2. Are per kilometre fares provided by carriers from the shared economy sector lower than those of traditional carriers? 3. Is the age of the car of carriers from the shared economy sector higher than that of traditional carriers? Testing for selected criteria always took place in pairs, i.e. dispatching - Liftago, dispatching - Taxify, dispatching - Uber, Liftago - Taxify, Liftago - Uber and Taxify - Uber. Of the total number of investigations (136), those which were not mentioned as an operator (3) and subsequently those with a missing criterion (19) were excluded.

Results. The Fischer parametric test of the difference of two scattering of two independent selections was used to test whether the two sets showed the same variance. In the case of the starting rate (in CZK) for the two groups of transport providers, the minimum and maximum rates of entry rates differed between the groups, but the differences in dispersion between the different carriers were not statistically significant. In none of the six possible pairs of transporters, differences in variance did not 
J. Mezulanik, L. Kmeco, M. Civelek., J. Kloudova. Transport Services in the Shared Economy Segment Compared to Traditional Taxi Services: The Case Study of the Czech Republic

exceed 0.025 quantile of Fischer distribution for the corresponding parameters at the significance level $\mathrm{n}_{\mathrm{x}}$.

Table 1. Starting rate of analysed ridesharing platforms

\begin{tabular}{|l|c|c|c|c|}
\hline \multirow{2}{*}{ Number } & \multicolumn{4}{|c|}{ Starting rate (v CZK ${ }^{*}$ ) } \\
\cline { 2 - 5 } & dispatching & Liftago & Taxify & Uber \\
\hline Min & 39 & 17 & 22 & 36 \\
\hline Max & 25 & 9 & 18 & 20 \\
\hline Average & 50 & 50 & 29 & 40 \\
\hline Variance & 33,74 & 32,68 & 24,72 & 25,28 \\
\hline Standard Deviation & 51,63 & 92,40 & 10,61 & 11,03 \\
\hline
\end{tabular}

Sources: developed by the authors on the basis of own calculation (2019).

*Note: 1 Czech crown = 25,62 Euro (11. 4. 2019)

At a rate per kilometre, the differences between the rate per kilometre between the classic taxi service (dispatching) and Taxify, as well as between the classic taxi service and the cars for Uber, exceeded the threshold of statistical significance (at 0.025 ). In the remaining four pairs, price distribution differences per kilometre were below statistical significance. In the case of Uber vehicles, the significantly higher maximum per-kilometre rate found does not matter. Even after excluding this value from the file examined, the conclusions would not change.

Table 2. The rates of analysed ridesharing platforms for per kilometre

\begin{tabular}{|l|c|c|c|c|}
\hline \multirow{2}{*}{} & \multicolumn{4}{|c|}{ Starting rate (v CZK*) } \\
\cline { 2 - 5 } & dispatching & Liftago & Taxify & Uber \\
\hline Number & 39 & 22 & 15 & 36 \\
\hline Min & 18 & 5,5 & 6 & 9,9 \\
\hline Max & 40 & 50 & 25 & 113,6 \\
\hline Average & 26,20 & 27,93 & 13,16 & 24,78 \\
\hline Variance & 46,68 & 73,12 & 45,27 & 336,98 \\
\hline Standard Deviation & 6,83 & 8,55 & 6,73 & 18,36 \\
\hline
\end{tabular}

Sources: developed by the authors on the basis of own calculation (2019).

Table 3. Age of the cars that were driven by the analysed ridesharing platforms

\begin{tabular}{|l|c|c|c|c|}
\hline & \multicolumn{4}{|c|}{ Age of the cars (years) } \\
\cline { 2 - 5 } & dispatching & Liftago & Taxify & Uber \\
\hline Number & 38 & 27 & 24 & 43 \\
\hline Min & $<1$ year & 1 & 1 & $<1$ year \\
\hline Max & 18 & 21 & 17 & 15 \\
\hline Average & 6,63 & 7,81 & 7,58 & 7,14 \\
\hline Variance & 23,18 & 31,04 & 26,41 & 9,65 \\
\hline Standard Deviation & 4,81 & 5,57 & 5,14 & 3,11 \\
\hline
\end{tabular}

Sources: developed by the authors on the basis of own calculation (2019).

In the case of the age of used cars, the variation range in the whole surveyed set was quite considerable, regardless of the operator, when some rides were made by virtually a new car which was only used for a few weeks, up to the 1997 production car. operator, only one failed to find out the year of 

Traditional Taxi Services: The Case Study of the Czech Republic

production. In total, 132 data could be analyzed. Even in one of the six possible pairs, the differences in the age distribution of the vehicle were not statistically significant at the alpha $=0.025$ level.

Conclusions. The original hypothesis that new market players who do not use the services of conventional dispatching will be closer to each other and will, in the interests of competitive advantage, form a certain opposition to classic taxi services on selected criteria. It is therefore probably only a marketing and media awareness that the customer will always pay less when using shared transport. Similarly, the assumption that the quality of the services provided under shared transport is lower due to the fact that these services are essentially or only minimally regulated is not confirmed. In both cases, the results of this partial research correspond to the other results that were found in the extensive research of the TACR Beta program. In this context, another direction of the survey is offered, which would evaluate the results in longitudinal research and compare the data found in an international context. There is also another direction of research that compares the price of transport services and their quality, which is artificially kept in the minds of customers with real status.

Author Contributions. Conceptualization, J. M., M. C.; methodology, J. M.; validation, J. M., L. K., resources, J. M., M. C.; data curation, J. M.; writing - original draft preparation M. C., J. M.; writing review and editing J.M., L. K.; visualization J.M., L. K.; supervision, J.M., L. K.; project administration J. M.

\section{References}

Alizadeh, T., Farid, Z. \& Sarkar, S. (2018): Towards Understanding the Socio-Economic Patterns of Sharing Economy in Australia: An Investigation of Airbnb Listings in Sydney and Melbourne Metropolitan Regions. Urban Policy and Research, DOI: 10.1080/08111146.2018.1460269.

American Public Transportation Association (2016). Shared Mobility And The Transformation Of Public Transit. Report, American Public Transportation Association. Retrieved from https://www.apta.com/resources/reportsandpublications/ Documents/APTA-Shared-Mobility.pdf, Accessed date: 17.03.2019.

Asirin, A. \& Azhari, D. (2018). Ride-Sharing Business Model For Sustainability In Developing Country: Case Study Nebengers, Indonesia, The 4th Plano Cosmo International Conference. IOP Conf. Series: Earth and Environmental Science, 158.

Belk, R. (2014). You Are What You Can Access: Sharing And Collaborative Consumption Online. Journal of Business Research, 67, 1595-1600.

Chang, H. H. (2017). The economic effects of Uber on taxi drivers in Taiwan. Journal of Competition Law \& Economics, 13(3), 475-500.

Cheng, M. (2016). Sharing economy: A Review And Agenda For Future Research. International Journal of Hospitality Management, $57,60-70$.

Cheng, X., Fu, S., \& Vreede, G.D. (2018). A mixed method investigation of sharing economy driven car-hailing services: Online and offline perspectives. Int J. Information Management, 41, 57-64.

Davidson, N.M., \& Infranca, J.J. (2016). The Sharing Economy As An Urban Phenomenon. Yale Law And Policy Review, 34 (215), 215-279.

de Souza Silva, L.A., de Andrade, M. O. \& Maia, M. L. A. (2018). How Does The Ride-Hailing Systems Demand Affect Individual Transport Regulation? Research in Transportation Economics, 69, 600-606.

Egan, M., Schaefer, M., Jakob, M. \& Oren, N. (2015). A Double Auction Mechanism for On-Demand Transport Prima Conference: International Conference on Principles and Practice of Multi-Agent Systems, Networks. DOI: 10.1007/978-3-31925524-8 38

Egan, M., Drchal, J., Mrkos, J., \& Jakob, M. (2018). Towards Data-Driven On-Demand Transport. EAI Endorsed Transactions on Industrial Networks and Intelligent Systems, 5(14), 1-10.

Gargiulo, E., Giannantonio, R., Guercio, E., Borean, C., \& Zenezini, G. (2015). Dynamic Ride Sharing Service : Are Users Ready To Adopt It? Procedia Manufacturing, 3, 777-784. http://DOl.org/10.1016/j.promfg.2015.07.329.

Greenwood, B. N., \& Wattal, S. (2017). Show Me the Way to Go Home: An Empirical Investigation of Ride Sharing and Alcohol Related Motor Vehicle. Homicide. MIS Quarterly, 41, 163-188.

Hall, J. D., Palsson, C. \& Price, J. (2017). Is Uber A Substitute Or Complement For Public Transit?, Working Papers tecipa-

585, University of Toronto, Department of Economics.

Henao, A. (2017). Impacts Of Ridesourcing - Lyft And Uber - On Transportation Including VMT, Mode Replacement, Parking, And Travel Behavior. (PhD Thesis), U.S: University of Colorado.

Jin, S. T., Kong, H., Wu, B., \& Sui, D. Z. (2018). Ridesourcing, The Sharing Economy, And The Future Of Cities. Cities, 76, 
J. Mezulanik, L. Kmeco, M. Civelek., J. Kloudova. Transport Services in the Shared Economy Segment Compared to Traditional Taxi Services: The Case Study of the Czech Republic

96-104.

Kljucnikov, A., Popesko, B. \& Kloudova, J. (2019). Economics Of The International Ridesharing Services - A Trap For Amateurs. Entrepreneurship And Sustainability Issues, 6(3), http://DOI.org/10.9770/jesi.2019.6.3(8).

Kljucnikov, A., Krajcik, V., Vincurova, Z. (2018). International Sharing Economy: the Case of AirBnB in the Czech Republic. Economics and Sociology, 11(2), 126-137. DOI:10.14254/2071-789X.2018/11-2/

Melo, S., Macedo, J. \& Baptista, P. (2019). Capacity-Sharing In Logistics Solutions: A New Pathway Towards Sustainability. Transport Policy, 73, 143-151.

Murphy, C., \& Felgon, S. (2016). Shared Mobility and the Transformation of Public Transit. Report submitted by the SharedUse Mobility Center (SUMC) for the American Public Transportation Association. $39 \mathrm{p}$.

PWC, (2015). Consumer Intelligence Series: The Sharing Economy. Retrieved from https://www.pwc.fr/fr/assets/files/pdf/2015/05/pwc_etude_sharing_economy.pdf Accessed: 17.03 .2019

Rayle, L., Dai, D., Chan, N., Cervero, R., \& Shaheen, S. (2016). Just A Better Taxi? A Survey-Based Comparison Of Taxis,

Transit, And Ridesourcing Services In San Francisco. Transport Policy, 45, 168-178.

Rogers, B. (2015). The Social Cost Of Uber. Temple University Legal Studies, Research paper, no. 2015-28.

Sharp, D. (2018). Sharing Cities for Urban Transformation: Narrative, Policy and Practice. Urban Policy and Research.

Sun, L., Wang, S., Liu, S., Yao, L., Luo, W., \& Shukla, A. (2018). A Completive Research On The Feasibility And Adaptation

Of Shared Transportation In Mega-Cities - A case study in Beijing. Applied Energy, 230, 1014-1033.

Schwieterman, J. P., \& Pelon, M. (2017). First Zipcar, Now Uber: Legal And Policy Issues Facing The Expanding «Shared Mobility» Sector In U.S. Cities. Belmont law review, 4, 109-137.

Schwieterman, J., \& Smith (2018). Sharing The Ride: A Paired-Trip Analysis Of Uberpool And Chicago Transit Authority Services In Chicago, Illinois. Research in Transportation Economics, 71, 9-16.

Stalmasekova, N., Genzorova, T., Corejovaa, T. \& Gasperova, L. (2017). The Impact Of Using The Digital Environment In Transport. TRANSCOM 2017: International scientific conference on sustainable, modern and safe transport. Procedia Engineering, 192, 231-236, DOI: 10.1016/.jproeng.2017.06.040.

Stuchlý, J. \& Suta, M. (2019). Participation In The Sharing Economy In The Czech Republic. SHS Web of Conferences 61, 01025. https://DOl.org/10.1051/shsconf/20196101025.

Tussyadiah, I. P. \& Pesonen, J. (2015). Impacts of Peer-to-Peer Accommodation Use on Travel Patterns. Journal of Travel Research. DOI: $10.1177 / 0047287515608505$.

Velychko, O., \& Velychko, L. (2017). Logistical modelling of managerial decisions in social and marketing business systems Journal of International Studies, 10(3), 206-219. DOI:10.14254/2071-8330.2017/10-3/15

Young, M., \& Farber, S. (2019). The Who, Why, And When Of Uber And Other Ride-Hailing Trips: An Examination Of A Large Sample Household Travel Survey. Transportation Research Part A, 119, 383-392.

Zervas, G., Proserpio, D. \& Byers, J. W. (2017). The Rise of the Sharing Economy: Estimating the Impact of Airbnb on the Hotel Industry. Journal of Marketing Research. Vol. LIV, 687-705. DOI: 10.1509/jmr.15.0204

Zhang, T. C., Jahromi, M. F. \& KizildagM. (2018). Value Co-Creation İn A Sharing Economy: The End Of Price Wars? International Journal of Hospitality Management, 71, 51-58.

Zhang, T., Bufquin, D. \& Lu, C. (2019). A Qualitative Investigation Of Microentrepreneurship In The Sharing Economy. International Journal of Hospitality Management, 79, 148-157.

Zuo, W.M., \& Chen, H.Q., 2017. Service innovation in the sharing economy environment: a TRIZ perspective. Nankai Bus. Rev., 20 (5), 175-184.

Zuo, W., Zhu, W., Chen, S., \& He, X. (2019). Service quality management of online car-hailing based on PCN in the sharing economy Electronic Commerce Research and Applications, 34.

Джірі Мезуланік, D.Sc., Університет бізнесу та права (Чеська республіка);

Любомир Кмеко, Ph.D., Коледж університету бізнесу в Празі (Чеська республіка);

Мехмет Чівелек, Ph.D., Університет Томаша Бата в Жиліні (Чеська республіка);

Джірка Клоудова, Ph.D., Університет підприємництва та права (Чеська республіка).

Транспортні послуги у галузі шерінгової економіки порівняно із традиційними службами таксі: досвід Чеської республіки

У статті проаналізовано основні проблеми та перспективи проникнення шерінгової економіки у галузь пасажирських перевезень Чеської республіки. Головною метою дослідження є порівняння нових райдшерінгових платформ, таких як: Uber, Liftago ma Taxifyand, з традиційними службами таксі. При иьому проаналізовано такі фрактори як: вартість послуг, основні характеристики автомобілів, що використовуються, та фрорма комунікації з клієнтами. Авторами зазначено, що вартість та якість послуг проаналізованих райдшерінгових платформ залежать від місцезнаходження та форми комунікації з клієнтами. У статті визначено, що у Чеській республіці існуючі райдшерінгові платформи надання транспортних послуг та особливості їх ффункціонування формують нові перспективні напрями дослідження шерінгової економіки. Методологію даного дослідження 
J. Mezulanik, L. Kmeco, M. Civelek, J. Kloudova. Transport Services in the Shared Economy Segment Compared to Traditional Taxi Services: The Case Study of the Czech Republic

засновано на опитуваннях та прямих спостереженнях у сфері надання послуг пасажирських перевезень. При цьому сценарії інтерв'ю та опитування розроблено з урахуванням принципу конфіденційності, щоб забезпечити більш відкриту комунікацію з респондентами. Респондентами дослідження стали користувачі як традиційних таксі, так і сучасних Uber, Liftago ma Taxify. Дослідження проведено у 2017/2018 роках у містах Прага та Острава (Чеська республіка). У свою чергу згенерований масив даних оброблено з використанням статистичної програми SPSS IBM за допомогою методів описової статистики. Отримані результати дослідження дають підстави зробити висновок, що форма комунікації з клієнтами не впливає на вартість наданих послуг на досліджуваних ринках, але впливає на вибір клієнтів при прийнятті рішення щодо замовлення. При цьому ціни нових райдшерінгових платформ (Uber, Liftago ma Taxify) є на рівні з традиційними постачальниками послуг пасажирських перевезень. Авторами наголошено, що результати дослідження є корисними як для компаній, що надають послуги пасажирських перевезень, так і для їх клієнтів.

Ключові слова: платформа, пасажирські перевезення, райдшерінг, райдсоурсинг, шерінгова економіка, транспортна галузь, Uber.

Manuscript received: 15.02.2019.

(C) The author(s) 2019. This article is published with open access at Sumy State University. 